\title{
AN ATTEMPT TO USE THE ROUNDNESS OF QUARTZ GRAINS FOR TILL STRATIGRAPHY
}

\author{
MARJATTA PERTTUNEN and HEIKKI HIRVAS
}

\begin{abstract}
PERTTUNEN, MARJATTA and HIRVAS, HEIKKI 1982: An attempt to use the roundness of quartz grains for till stratigraphy. Bull. Geol. Soc. Finland 54, 1-2, 25-33.

The roundness of quartz grains in till stratigraphical samples was studied from Central and eastern Finland. The results show slight differences between the various portions of the till beds as well as areal differences. The surface texture of the quartz grains in till studied with the aid of scanning electron microscopy displays glacial and eolian features. Examination of the roundness and surface texture seems to be a useful tool in till stratigraphical studies.

Marjatta Perttunen and Heikki Hirvas, Geological Survey of Finland, Kivimiehentie 1, SF-02150 Espoo 15, Finland.
\end{abstract}

\section{Introduction}

The purpose of this study was to test whether the round ness of the quartz grains in a till matrix could be used as a criterion in till stratigraphy. The study was based on material collected by the Geological Survey of Finland during the research project »Glacialgeological studies for mineral exploration". Marjatta Perttunen is responsible for the studies and conclusions on the roundness and surface texture of the quartz grains. The till stratigraphical data (fabric analyses, pebble counts) are based on a study by Hirvas (1980), who describes from Central and eastern Finland (Fig. 1) two or three different till layers, often with interbedded sand layers. The till layers were deposited by the continental ice sheet flowing from various directions during the late Weichselian stage. The till units are informally termed the older, the younger and the youngest till beds. The most common till on the surface is the younger till.

Fourteen samples from six profiles within the till sequence were analysed for the roundness of the quartz grains. From 100 to 130 quartz grains from the $1-1.2 \mathrm{~mm}$ fraction of the till and sand samples were examined. The roundness of the quartz grains was determined with the aid of a mechanical graniformameter developed by Krygowski (1964), who has used the following roundness classes: $\gamma_{2}=$ very rounded, $\gamma_{1}=$ rounded, $\beta_{2}=$ subrounded,$\quad \beta_{1}=$ subangular, $\quad \alpha_{2}=$ angular, $\alpha_{1}=$ very angular. The index of abrasion $\left(\mathrm{W}_{0}\right)$ and the index of heterogeneity $(\mathrm{Nm})$ of the quartz grains were also determined. The roundness of the quartz grains in tills has been examined earlier for till transport and deposition studies by a few authors, e.g. Krygowski 1964; Krygowski and Krygowski 1965; Seppälä 1971; and Perttunen 1977. 


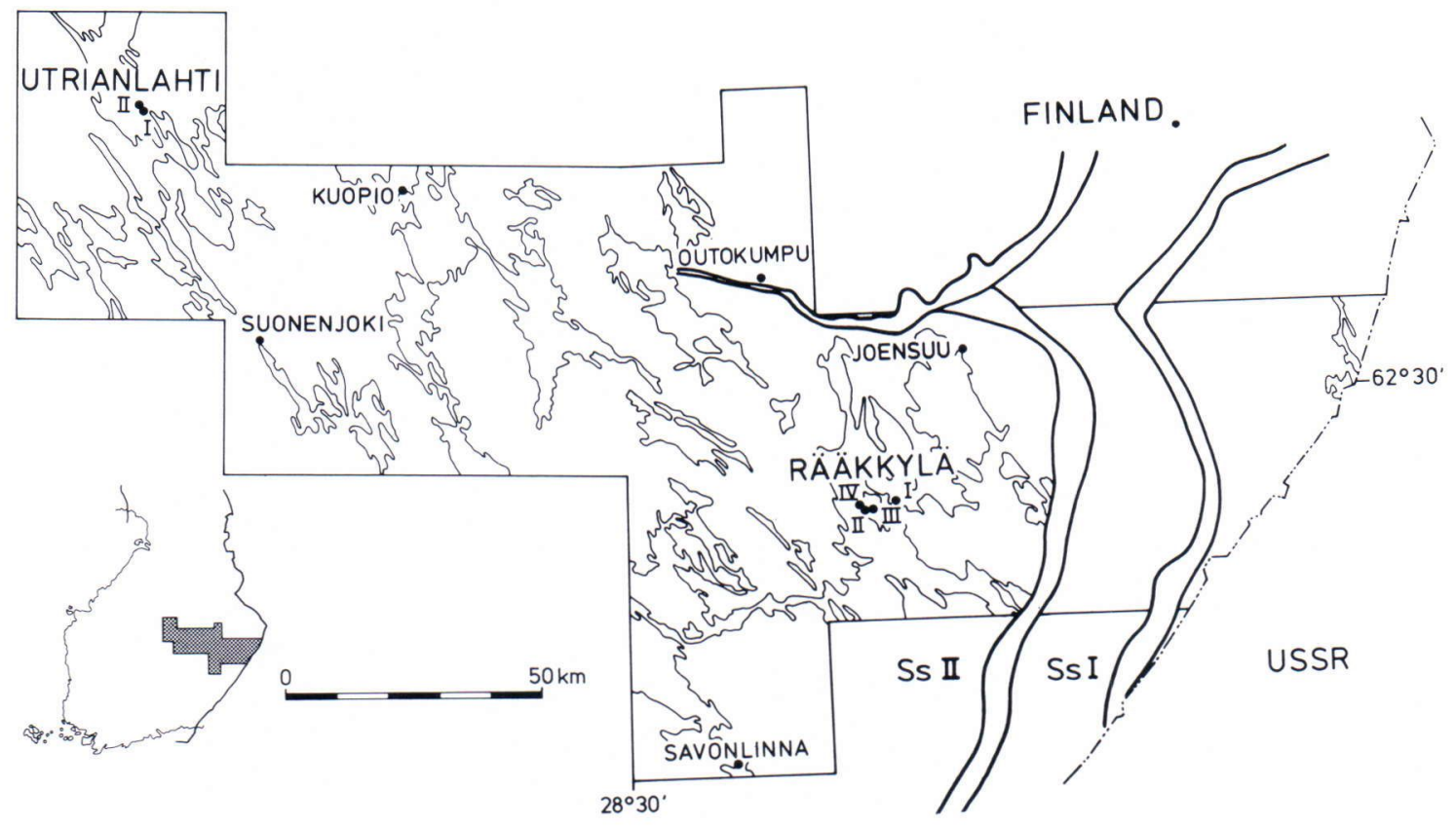

Fig. 1. Location of the study areas.

\section{I $89105 / K R N / 78$ UTRIANLAHTI}

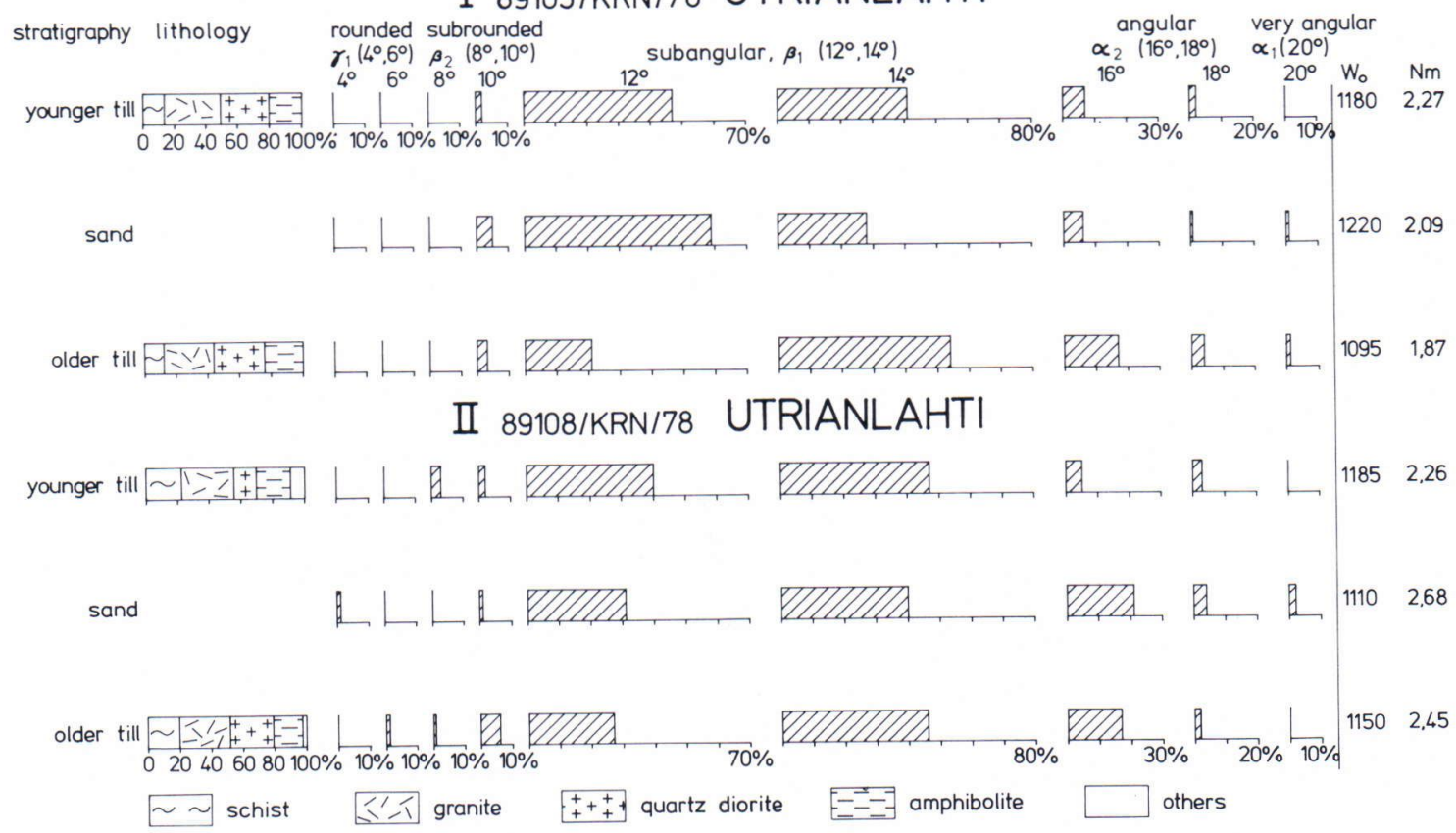

Fig. 2. Stratigraphy, lithology and roundness of the quartz grains in Profile I and II, Utrianlahti. $\mathrm{W}_{0}=$ index of abrasion, $\mathrm{Nm}=$ index of heterogeneity. 


\section{Roundness of the quartz grains}

The till and sand beds differ somewhat in the degree of roundness of the quartz grains.

\section{Profile I, Utrianlahti (Fig. 2)}

In Profile I, Utrianlahti, the 2-metre thick younger till is underlain by sand and older till (Fig. 3). Both till beds have similar fabrics. The fabric of the older till in this profile is exceptional in this area. A possible explanation is that the fabric analysis of the older till was done on the uppermost portion, which was deformed by the younger ice flow, although the sand layer does not manifest any deformation structures. The pebble counts have given similar results, and the quartz derives from granites and quartz diorites.

The roundness of the quartz grains varies in the three layers. Detailed examination of the quartz grains, rolled in angle class $12^{\circ}\left(\beta_{1}\right)$, shows that the roundness in the older till is less than in the younger till. The quartz grains in the sand layer have the highest degree of roundness. In all the samples the majority of the quartz grains belong to the subangular roundness class. All the beds include a few percentages of angular and subrounded grains.

\section{Profile II, Utrianlahti (Fig. 2)}

Profile II, Utrianlahti, is at a distance of $800 \mathrm{~m}$ from Profile I. The stratigraphy is similar: younger till, sand and older till (Fig. 3). Fabric analyses show differences in the ice flow directions between the younger and older tills. The directions are typical of the local trend in the tills. Pebble counts revealed that both tills contain equal proportions of schists and granites, but that the older till contains a greater proportion of quartz diorite clasts owing to the longer transport distance in the quartz diorite bedrock area.

The variations in the roundness of the quartz grains in Profile II are similar to those

\section{Utrianlahti}
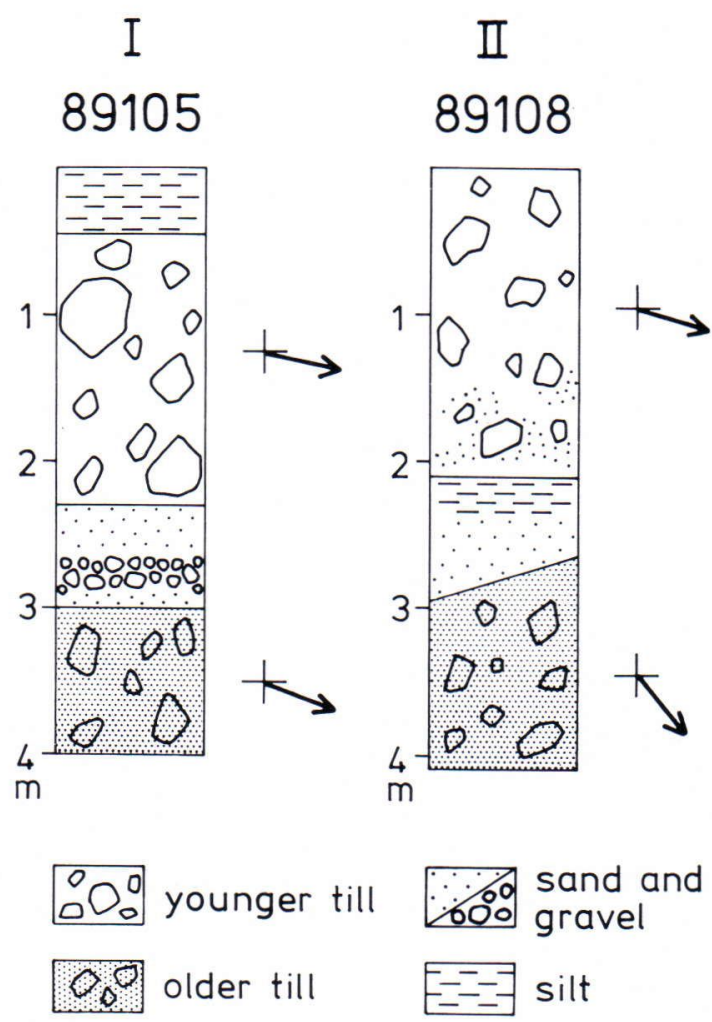

Fig. 3. Stratigraphy and fabrics in Profiles I and II, Utrianlahti.

in Profile I. The quartz grains in the younger till have the highest roundness. This is shown by the grains of the angle class of $12^{\circ}\left(\beta_{1}\right)$ and the angle class of $16^{\circ}\left(\alpha_{2}\right)$. The roundness of the quartz grains in the interbedded sand is less in Profile II than in Profile I. Subangular grains predominate in all beds. Angular and subrounded grains are less common. One per cent of the quartz grains in the older till and in the overlying sand are rounded $\left(\gamma_{1}, 4^{\circ}-6^{\circ}\right.$ class).

\section{Profile I, Rääkkylä (Fig. 4)}

In Profile I, Rääkkylä, the younger till lies directly on the older till (Fig. 5). Their fabrics 


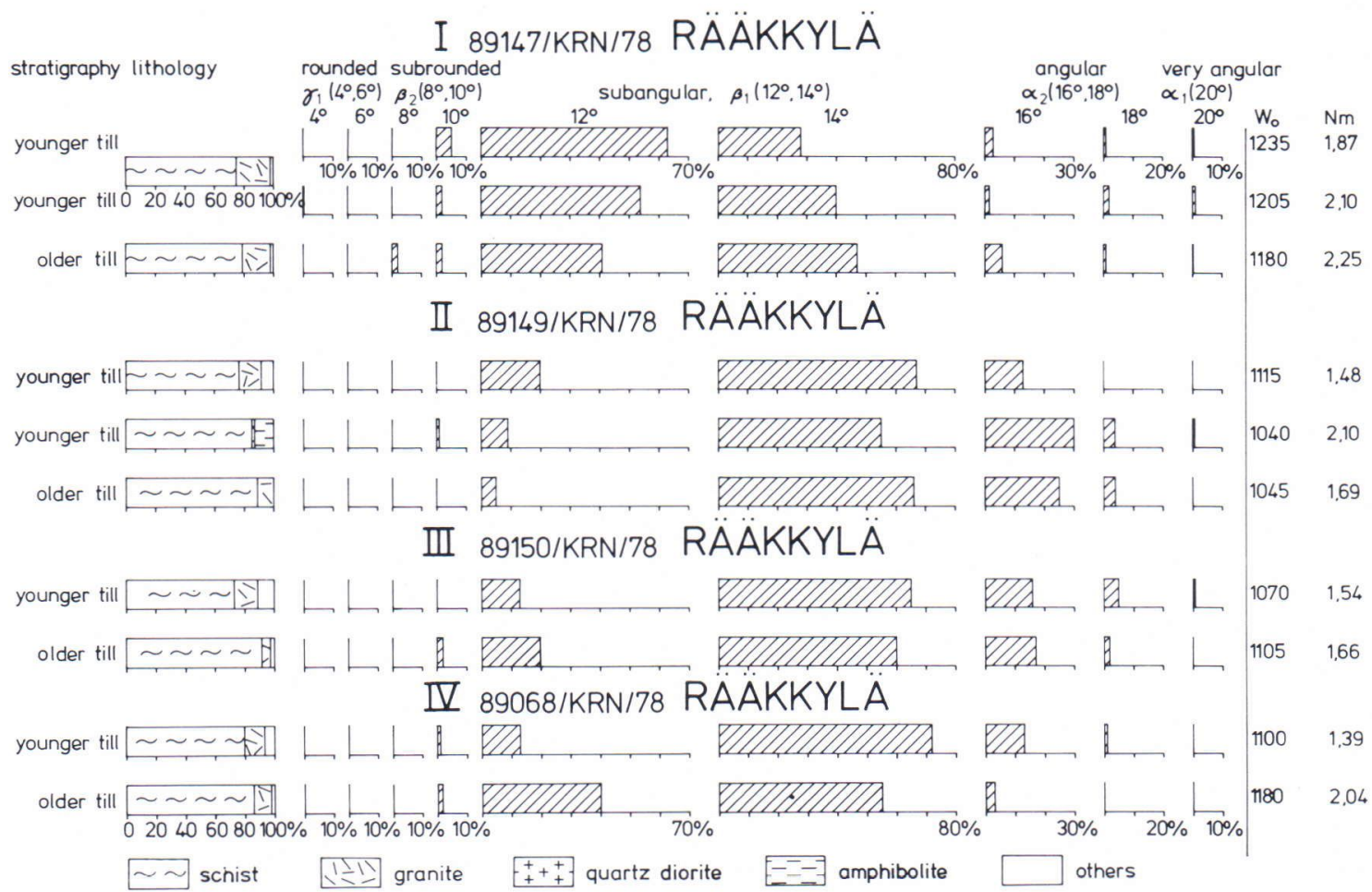

Fig. 4. Stratigraphy, lithology and roundness of the quartz grains in Profiles I, II, III and IV, Rääkkylä. $\mathrm{W}_{0}=$ index of abrasion, $\mathrm{Nm}=$ index of heterogeneity.

are different. The older till contains more local schist clasts than does the younger till.

The roundness of the quartz grains in this profile displays trends similar to those in the profiles of Utrianlahti. The roundness increases gradually from the older to the younger till. Subangular grains dominate. The older till has some grains in the angle class of $8^{\circ}\left(\beta_{2}\right.$, subrounded). Grains of the angle class of $10^{\circ}\left(\beta_{2}\right.$, subrounded) exist in both tills.

\section{Profile II, Rääkkylä (Fig. 4)}

Profile II, Rääkkylä, contains both younger and older till (Fig. 5). The highest proportion of schists shown by the pebble counts on the older till indicates that the material in the older till is more local in origin than that in the younger till.

As in Profile I and the profiles of Utrianlahti the roundness of the quartz grains increases from the base to the upper portion of the profile. Angular grains (angle classes of $16^{\circ}$ and $18^{\circ}$ ) predominate in the highest portions of the older till and in the lower portion of the younger till. A similar trend is displayed by the index of abrasion $\left(\mathrm{W}_{0}\right)$, whereas the index of heterogeneity $(\mathrm{Nm})$ is more variable. On the whole, in the degree of roundness the lower part of the younger till is more similar to the older till than to the upper part of the younger till. The grains of the angular and subangular classes predominate in all the samples, whereas the subrounded grains are almost completely lacking. 


\section{Rääkkylä}
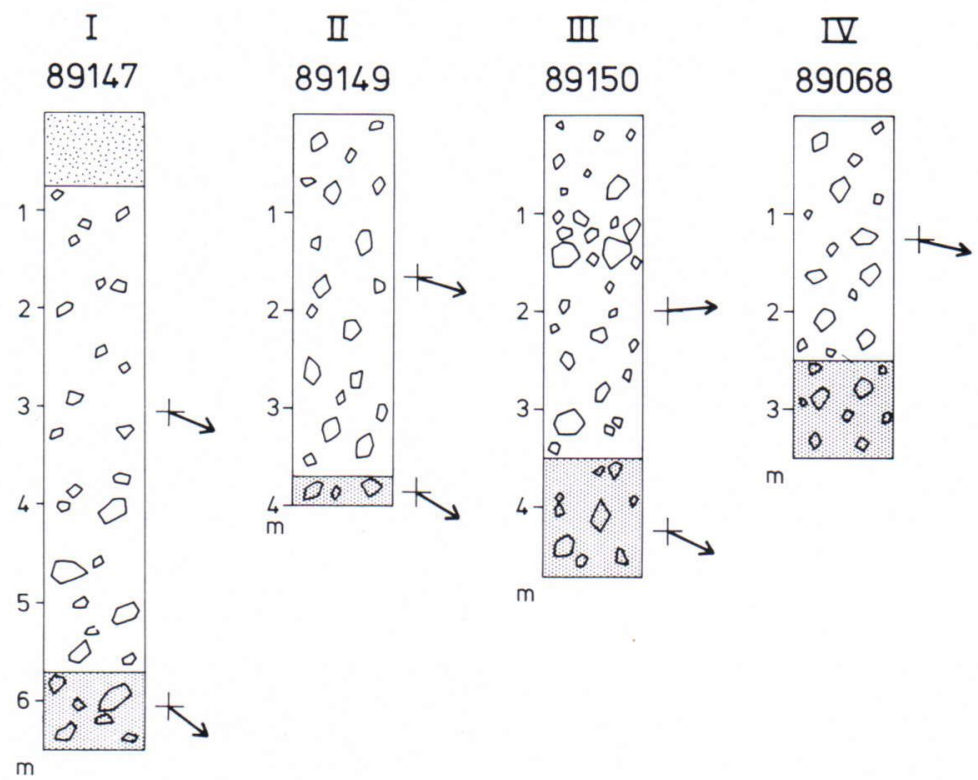

\section{$P_{0} 0$ younger till $0^{\circ} 0$ older till sand}

Fig. 5. Stratigraphy and fabrics in Profiles I, II, III and IV, Rääkkylä.

Profile III, Rääkkylä (Fig. 4)

The stratigraphy of Profile III shows a younger till overlying an older one (Fig. 5). The two till beds differ in fabrics. The pebble counts show that the proportion of granites is higher in the younger than in the older till.

This profile is unlike any of the other profiles already described. The angle class of $12^{\circ}$ exhibits more subangular grains in the older than in the younger till. The subangular group predominates in both till beds.

\section{Profile IV, Rääkkylä (Fig. 4).}

The stratigraphy is the same as in the other Rääkkylä profiles: the younger till overlies the older till (Fig. 5). Fabric analysis shows the same orientation for the younger till as in
Profiles I and II in the Rääkkylä area. The older till was not subjected to fabric analysis. Pebble counts show more schists in the older till.

The results for roundness are similar to those in Profile III. The quartz grains of the older till are more rounded. In the angle class of $12^{\circ}$, the proportion of subangular grains in the older till is three times that in the younger one; likewise the proportion of angular grains is conspicuously smaller in the older till.

\section{Conclusions}

The index of abrasion $\left(\mathrm{W}_{0}\right)$ and the index of heterogeneity $(\mathrm{Nm})$ of the younger till are the same $(1180,1185)$ in Profiles I and II in the Utrianlahti area. Furthermore, the roundness of the quartz grains in the older till in both 

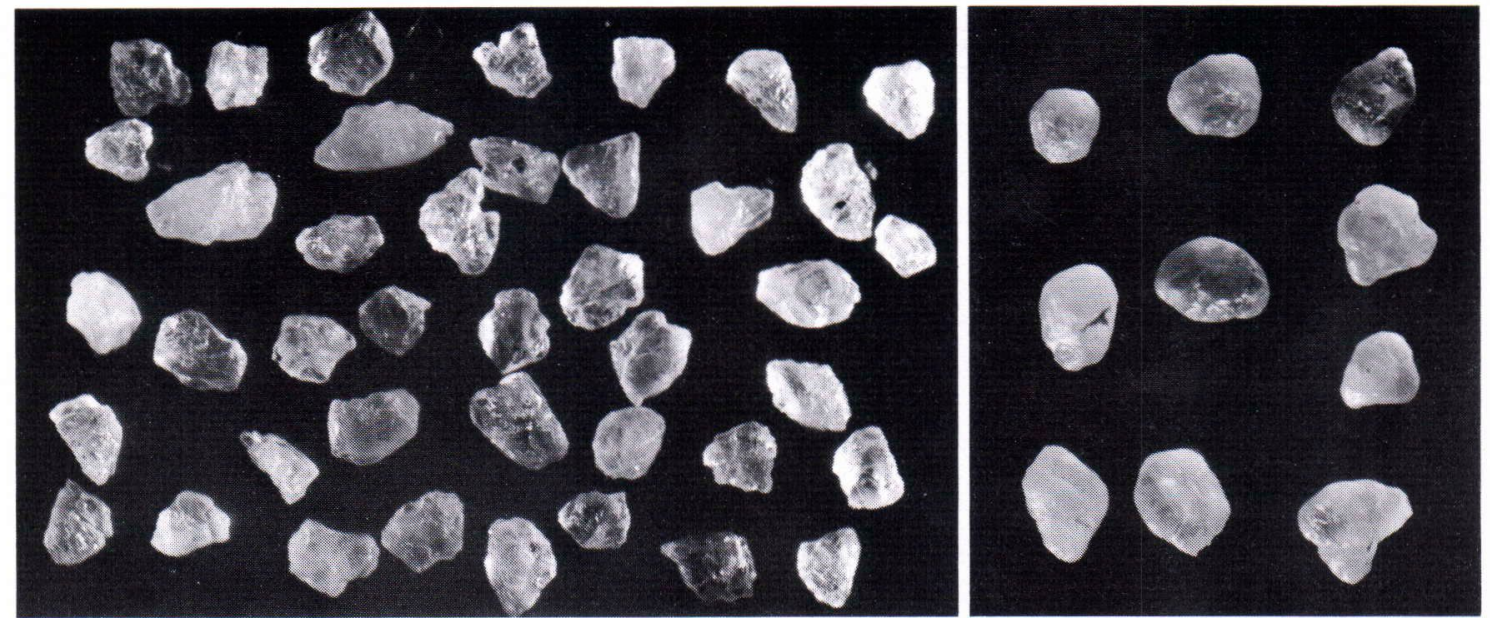

Fig. 6. Clear angular and subangular quartz grains (left), pitted subrounded quartz grains (right) from the till in Rääkkylä. 1-1.2 mm fraction.

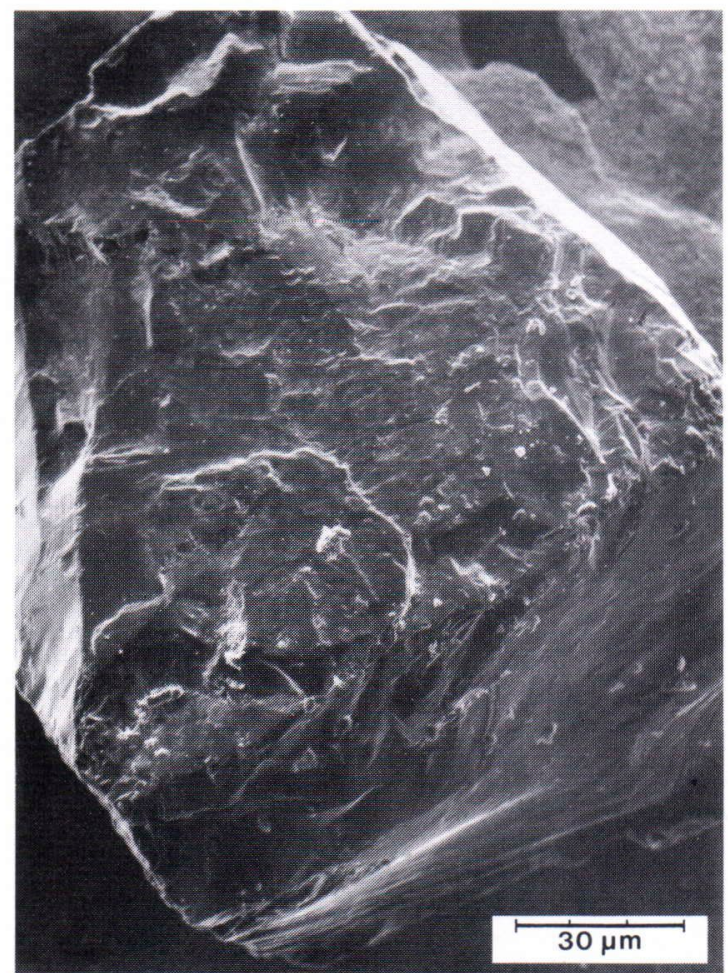

Fig. 7. A typical glacial-featured quartz grain with very high relief from the till in Rääkkylä.

profiles is rather similar $(1095,1150)$. The correlation between the till beds of the same age seems obvious.

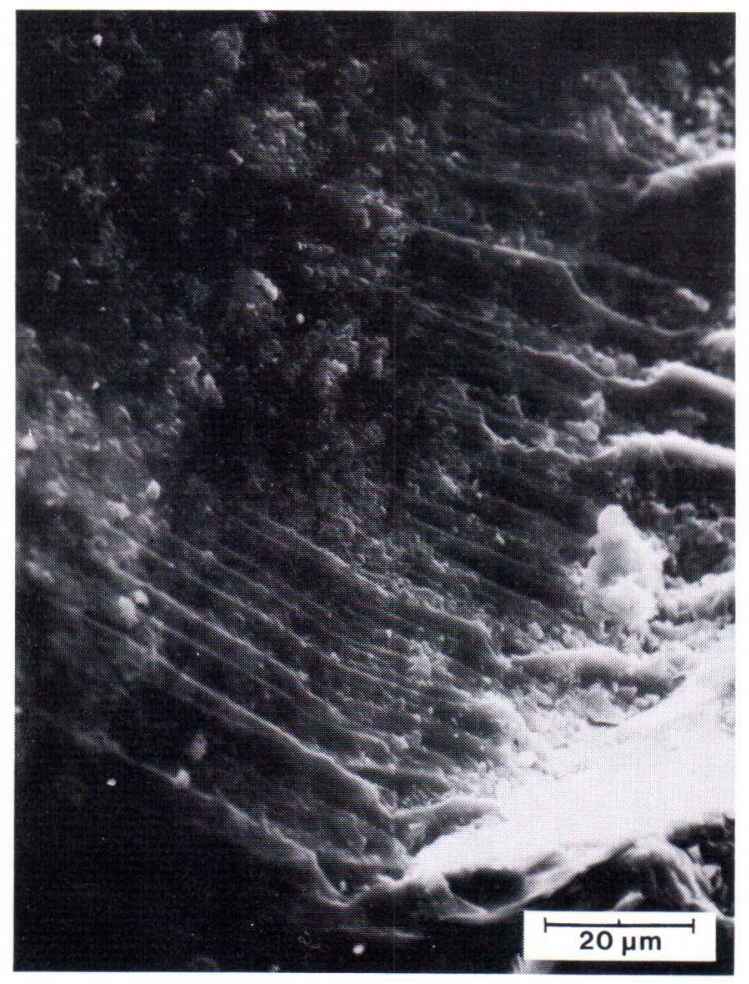

Fig. 8. Good parallellel steps of the quartz grain seen in photo 7 .

All four profiles in the Rääkkylä area overlie schist bedrock. It is remarkable that the value of abrasion ( $\left.\mathrm{W}_{0}, 1180\right)$ is constant in 


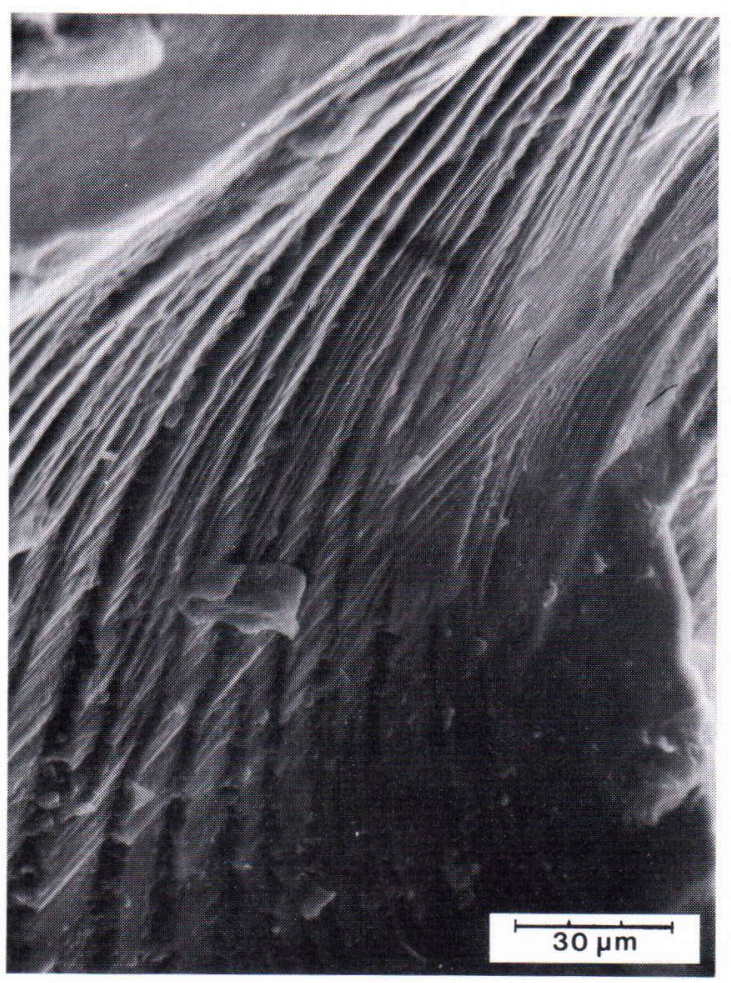

Fig. 9. Arc-steps of the quartz grain seen in photo 7.

older till in Profiles I and IV. In Profiles II and III the index of $W_{1}$ ) varies somewhat (1045 and 1105) in the older till. Furthermore, the younger tills are similar, the value of $\mathrm{W}_{0}$ being 1070, 1100 and 1115. The exception is Profile $\mathrm{I}$, which has a high value of abrasion $\left(\mathrm{W}_{0}, 1235\right)$ for the younger till.

Profiles II-IV are near each other, but Profile $I$ is $7 \mathrm{~km}$ to the east. Fabric analyses indicate that the younger till was deposited by ice flowing from west to east. The source rocks are the granitic rocks to the west of the profiles. The higher degree of roundness of the younger till in Profile I is attributed to the longer transport distance, $7 \mathrm{~km}$, by the late Weichselian continental ice. Otherwise, the correlation between the till beds of the same age is as distinct as in the Utrianlahti area.

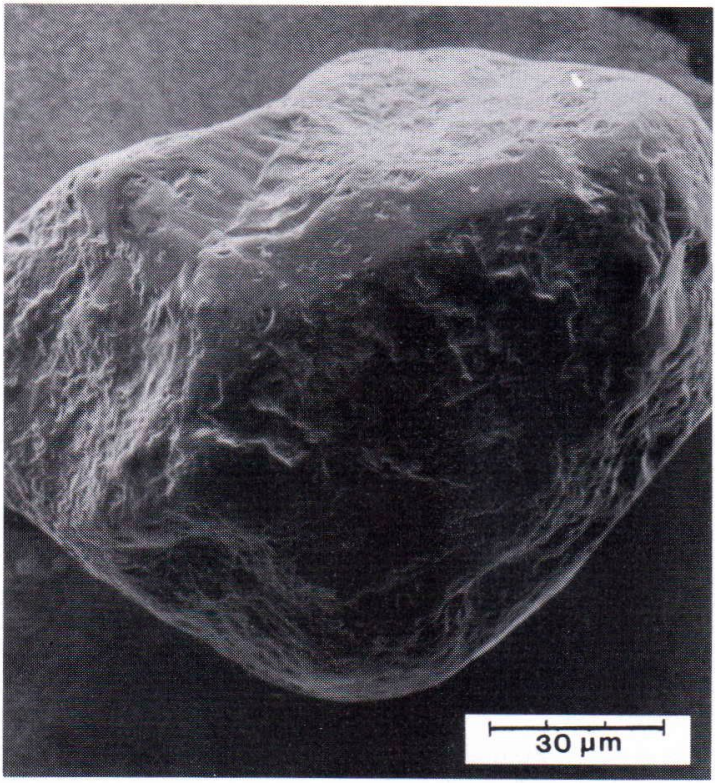

Fig. 10. A pitted quartz grain from the till in Rääkkylä. Eolian origin.

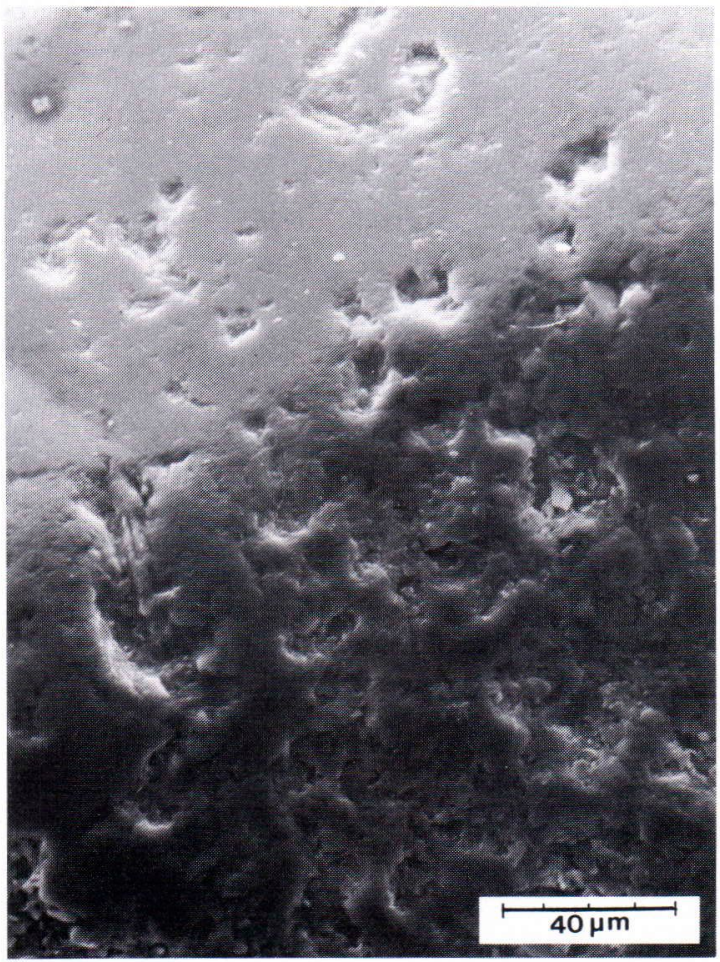

Fig. 11. Detail of the quartz grain seen in photo 10 . The effect of solution and precipitation is clearly visible. 


\section{Occurrence of pitted quartz grains}

Taken from the drumlins, the two profiles of Utrianlahti have a small percentage of pitted grains in all beds.

The proportion of pitted quartz grains is lower in the profiles of Rääkkylä, just within the Salpausselkä ice marginal formations than in the Utrianlahti area. The distribution of the pitted quartz grains is as follows: In Profile I all the beds have a small percentage; in Profile II only the younger till contains these grains; in Profile III pitted grains are few but they are present in all the units; in Profile IV they are present only in the older till. The pitted grains were probably transported from the glacier by winds during each glaciation stage and were incorporated into the till during deposition. They may also have derived from reworked older sediments.

\section{Surface texture of the quartz grains}

The surface textures of some quartz grains of the samples from Utrianlahti and Rääkkylä were examined by scanning electron microscopy (SEM). Both clear angular and subangular grains and pitted subrounded grains were used for the study (Fig. 6).

The surface texture of the angular and subangular grains revealed characteristic features produced by glacial action (e.g. Krinsley and Donahue 1968, Whalley and Krinsley 1974). Figure 7 shows a typical glacial-featured quartz grain with very high relief, an irregular, rough glacial outline, conchoidal features and breakage blocks, parallel and sub-parallel steps and arc-steps. Fig. 8 displays good parallel steps. They are probably caused by shear stress as are the arc-steps common on conchoidal breakage faces with regular spacing (Fig. 9). According to Krinsley and Donahue (1968, p. 746), they probably represent percussion fractures. Some comminution flakes occur on the surface of the grain.

Fig. 10 illustrates a pitted quartz grain from the older till. Fig. 11 shows a detail of the same grain. Diagenesis (solution and precipitation) shows up clearly on lower portions of the grain (Coch and Krinsley 1971, p. 433). Glacial abrasion with striations and etch pits is revealed on the upper surface of the grain. Solution and precipitation are ty pical of coldclimate dune material (Krinsley and Doornkamp 1973). Nún̄ez and Alhonen (1974) have described eolian material with similar features from Lammi, Finland. The pitted grains seem to reflect the eolian environment.

\section{Final remarks}

The quartz grains exhibit only slight differences in roundness. Nevertheless, detailed examination reveals a certain trend. In the study area the roundness of the quartz grains appears to be a useful tool in establishing the differentiation of till layers. It may be applicable in shield areas similar to that discussed in this study. Furthermore, the roundness of the quartz grains and surface textures reflect different origins and transport distances of the material.

Acknowledgements. The authors are indebted to Mrs. Tuula Hautala for taking the electron microscope photographs, to Professors Kauko Korpela and Raimo Kujansuu for critically reading the manuscript. 


\section{References}

Coch and Krinsley, 1971. Comparison of stratigraphic and electron microscopic studies in Virginia Pleistocene coastal sediments. J. Geol. 79, 426-437.

Hirvas, Heikki, 1980. Moreenistratigrafiasta ja sen merkityksestä malminetsinnässä. Geologi 32, $33-37$.

Krinsley, David H. and Donahue, Jack, 1968. Environmental interpretation of sand grain surface textures by electron microscopy. Geol. Soc. Am. Bull. 79, 743-748.

Krinsley, D. H. and Doornkamp, J. C., 1973. Glossary of quartz sand grain textures. Cambridge University Press. Cambridge, England. 91 p.

Krygowski, B., 1964. Graniformametria mechaniczna. Teoria, Zastosowanie. Poznań Tow. Przyj. Nauk II (4). 112 p. German summary. Krygowski, B. and Krygowski, T. M., 1965. Mechanical method of estimating the abrasion grade of sand grains (mechanical graniformametry). J. Sedim. Petrol. 35, 496-499.

Núñez, Milton and Alhonen, Pentti, 1974. Scanning electron microscopic examination of the deposits covering the southeastern slope of the Onnenvuori hill in Lammi, southern Finland. Bull. Geol. Soc. Finland 46, 109-116.

Perttunen, Marjatta, 1977. The lithologic relation between till and bedrock in the region of Hämeenlinna, southern Finland. Geol. Surv. Finland, Bull. 291. 68 p.

Seppälä, Matti, 1971 Evolution of eolian relief of the Kaamasjoki-Kiellajoki river basin in Finnish Lapland. Fennia 104. 88 p.

Whalley, W. Brian and Krinsley, David H., 1974. A scanning electron microscope study of surface textures of quartz grains from glacial environments. Sedimentology 21, 87-105.

Manuscript received, January 28, 1982 